\title{
Re-living a Common Future in the Face of Ecological Disaster: Exploring (Elements of) Guarani and Kaiowá Collective Memories, Political Imagination, and Critiques
}

\author{
Susanne Normann ${ }^{1}$ (D) \\ Received: 29 October 2020 / Revised: 10 January 2021 / Accepted: 12 January 2021 / \\ Published online: 15 March 2021 \\ (C) The Author(s) 2021
}

\begin{abstract}
How to re-member a fragmented world while climate change escalates, and green growth models reproduce coloniality, particularly in Indigenous territories? What can be the concrete contributions from different scholarly disciplines to a broader decolonial project? These questions are debated by decolonial scholars who call to re-think our practices within academic institutions and in the fields that we study. This article contributes with a decolonial perspective to sociocultural psychology and studies on Indigenous knowledges about climate change. Through ethnographic methods and individual and group interviews, I engage with indigenous Guarani and Kaiowá participants' knowledges and practices of resilience opposing green growth models in the Brazilian state Mato Grosso do Sul. Their collective memory of a different past, enacted through narratives, rituals, and social practices, was fundamental to imagine different possible futures, which put in motion transformation processes. Their example opens a reflection about the possibilities in connecting sociocultural psychology's work on collective memory and political imagination to the broader decolonial project, in supporting people's processes of re-membering in contexts of adverse conditions caused by coloniality and ecological disaster.
\end{abstract}

\section{Introduction}

Indigenous peoples denounce how 'green' economies and projects of climate-change mitigation implemented in their territories often add to the burdens that adapting to dramatically changing weather patterns pose to their ways of life. Their demands are slowly gaining traction in international forums and include greater emphasis on guaranteeing their rights when mitigation projects are implemented (Newell \& Taylor, 2020). However, these advances run parallel to increasing pressures on Indigenous territories by extractivist industries often promoted as 'green', or climate-friendly.

In 2019, two UN reports recommended states to include Indigenous knowledge (IK) in mitigation agendas (IPBES, 2019; IPCC, 2019). Research on how IK can help in dealing

Susanne Normann

susanne.normann@sum.uio.no

1 Centre for Development and the Environment (SUM), University of Oslo (UiO), Oslo, Norway 
with ecological disaster can be organised into two main areas. One approach focuses on the technical aspects of specific climate-change adaption in Indigenous communities, proposing ways to include these and other technical knowledges in global or national mitigation agendas. (See for instance Ajani et al., 2013; Nyong et al., 2007). Other studies, with an expressed or implicit systemic or decolonial critique (Ndlovu, 2014; Whyte, 2017), recognise Indigenous knowledges in plural and have forwarded how they often are fundamentally opposed to hegemonic Western models of climate-change mitigation. These scholars understand the development of unsustainable modernity and ecological crisis as intrinsically connected to the history of colonialism and continuing coloniality (Adams et al., 2018a; Trawick et al., 2015) that acts to dispossess many Indigenous peoples of their territories and future self-determination possibilities.

Within the critical sub-disciplines of psychology, such decolonial perspectives have undergone a resurgence, with internal critiques of how hegemonic psychologic science may have acted to maintain oppressive systems (Adams et al., 2018a; Bhatia \& Priya, 2018). Such studies explore possible contributions from psychology to the broader interdisciplinary decolonial project (Maldonado-Torres, 2017; Pickren, 2018b). Sociocultural psychologists have echoed this growing interest in decolonial approaches (Bradbury, 2019; Pickren, 2018a; Glăveanu \& Sierra, 2015), in particular, studying the historical colonisation of psychological science itself, where the emphasis on meaning is replaced with fragmentation or positivism (Jovanović, 2019; Pickren, 2018a). This article seeks to contribute to the broader project of developing decolonial psychological thinking and practices by presenting an empirical study. Combining a loose framework of recent sociocultural psychology work on collective memory and political imagination (de Luna, 2018; de Saint-Laurent, 2018b; Jovchelovitch \& Hawlina, 2018) with decolonial theory, I explore meaning-making about climate change and climate- change mitigation among the indigenous Guarani and Kaiowá of the southern cone of the Brazilian centralwestern state of Mato Grosso do Sul (MS), where an agro-export model based on cattle, and sugarcane, soybean and corn as 'flex crops', has developed.

Studying the situation of the Guarani and Kaiowá is both meaningful and challenging. The region's agribusiness sector originated in an epoch when climate change was absent from globalised discussions. In recent decades, however, increasing the production of biodiesel and ethanol from soybean, corn and sugarcane, re-branded as 'green' and 'sustainable', have been included in Brazil's commitments to the Paris Agreements (Lima et al., 2020). The hardships imposed on the Guarani and Kaiowá, who were displaced from their lands, are widely recognised (Ioris, 2020; Brand, 2004; Benites, 2012)—indeed, almost as a dystopic worst-case scenario of the violent consequences that green economies may have on Indigenous ways of life. Certain ways of life — even humans - may become disposable in such green models, reflecting what political scientist and philosopher Achille Mbembe (2019b) conceptualised as necropolitics. According to Mbembe, the sum of extractivism, politics, anthropogenic climate change, biodiversity losses and land-use change, and other changes may soon turn places on earth into uninhabitable hothouses (EGSVL, 2019). As the pace is uneven, places and times where adversity is high can turn into laboratories of possibilities of human (and non-human) life resilience in conditions of adversity (Ibid).

While this all-encompassing and escalating situation brings shifts in how we frame the future of life (Mbembe, 2019a) and dystopia replaces progress-optimism, the re-prefix appears frequently in diverse disciplines that study climate change (e.g. Federici \& Linebaugh, 2018; Jepson, 2019; Woodbury, 2019). Postcolonial and decolonial scholars note the importance of the recovery of memories and practices, re-membering 
(Mbembe, 2019a; Ndlovu-Gatsheni, 2020; wa Thiong'o, 2009), and re-existence (Mignolo $\&$ Walsh, 2018) to change our planet's dangerous course.

My study started with an open research question concerning the knowledge, meaningmaking and collective strategies aimed at increasing resilience among the Guarani and Kaiowá confronted with climate change and 'green' agribusiness. Realising the central position of memory work in their multiple political strategies, I focus on exploring how the enactment of collective memory among the Guaraní and Kaiowá informs their multiple strategies for building resilience. The study seeks to contribute with a decolonial perspective to the psychology of climate change. I anchor it in a conceptual framework that combines sociocultural psychological approaches to the interactions of memory, imagination, human action, and transformation with postcolonial and decolonial work on re-membering. My main objectives are two: to contribute to the political field that positions Indigenous knowledges as fundamental in climate change mitigation agendas and to explore how sociocultural research on collective memory and political imagination (de Saint-Laurent, 2018b; Jovchelovitch \& Hawlina, 2018) can contribute to the broader decolonial project, and in particular to re-membering and recovery processes in communities resisting the adverse conditions engendered by ecological devastation. I find that in this research setting where the agribusiness model creates a toxic environment of human alienation, the Guarani and Kaiowá participants' engagement with collective memory provided possibilities of imagining a different future. Their collective memory became a tool for generating individual and collective action, putting in motion processes to provoke ruptures in sociogenesis (Zittoun \& Gillespie, 2015), and generate ecological resilience.

\section{Theoretical Background}

\section{Decoloniality, Re-existence, and Re-membering}

Decoloniality has profound and diverse roots within Latin American realities, scholarship, and anticolonial struggles (e.g. Fanon, 2017; Martín-Baró, 1994). The concept of re-existence (Mignolo \& Walsh, 2018) points to how Indigenous peoples and other marginalised communities who live colonial difference enact ways of being, thinking, knowing, theorising, analysing, feeling, acting, and living that can disrupt 'modern/ colonial/capitalist/hetero-patriarchal matrices of power'(Mignolo \& Walsh, 2018, p. 101). Quoting the Afro-Ecuadorian pedagogue and historian Juan García Salazar, Mignolo \& Walsh (2018, p. 43) explain this way of learning as learning casa adentro: reclaiming the 'collective memory, philosophies and knowledges inherited from the ancestors, histories of acts of resistance, and other elements that mark and permit our difference, our forms of life in community'.

From the African continent, postcolonial scholars highlight the relevance of 're-membering'(Ndlovu-Gatsheni, 2015; wa Thiong'o, 2009) for African communities after lengthy colonial dismemberment. In such re-membering, language recovery and memory work have been fundamental. Mbembe (2019a) suggests the relevance of this for all humanity, in the face of fragmentation within and between communities, escalating colonialism, and ecological destruction with planetary consequences. The concept of re-membering is also used within feminist research, connecting it further to the body and subjective experience after exposure to violence and trauma (Bueno-Hansen, 2018); in 
critical Community Psychologists' PAR designs (Fine \& Torre, 2004); and in revitalisation processes among Indigenous communities, where language and other cultural features are recovered (Kalafatic, 2020). It has been linked to narrative therapeutic practices challenging Western cultural individualist and self-isolating beliefs (White, 2007); and to matters of de-ideologisation and recovery of meaningful identity and relationships (Afuape, 2011; Martín-Baró, 1994). All these works connect memory to recovery from trauma or the re-construction of meaningful intersubjectivity or connection between communities, frequently in colonial situations where human communities have been literally dis-membered, or torn apart. 'Re-membering' entails a creative innovation, not a recovery of the original etymological meaning. The 're' prefix means to recover, but 'member' here is unrelated to the word meaning body parts or group membership: it is related to 'memoir', and the $b$ reflects phonetical transitions over time (Dictionary, n.d.).

These processes of re-membering, re-existence, and resistance unfold across many places and times. But what can be the roles of scholars interested in supporting or promoting a decolonial praxis? In the next section, I propose one possible contribution from sociocultural psychology on collective memory and political imagination to supporting such re-humanisation processes.

\section{Cultural Psychology, Collective Memory, and Imagination}

Cultural psychologists have discussed how their field can contribute to the broader decolonial project (Bradbury, 2019; Glăveanu \& Sierra, 2015; Pickren, 2018a) and support social transformation processes (Alphen \& Normann, 2020). Work connecting collective memory to human imagination may be one such contribution. Psychological research on individual and collective memory, and the linkages to the present, has long traditions (Brockmeier, 2002). de Saint-Laurent (2018b) is among those who propose a more direct link between how we consider the past and how we imagine our future. Memory is seen as an active reconstruction (Bartlett, in de Saint-Laurent, 2018a, b) that requires a level of imagination. Simultaneously, memory becomes transformed by imagination to produce something new (Vygotsky, 2004; de Saint-Laurent, 2018b)—like engaging in the search for political goals (Brescó \& Wagoner, 2015). The narratives we create about our past also announce the future we are enacting, providing the 'material' for imagining and constructing this future, also for utopias or dreams of a better future that can guide sociogenesis (Jovchelovitch \& Hawlina, 2018). As decolonial scholars and communities alike call for re-thinking, re-imagining, and re-membering our fragmented world, the meticulous theoretical work of various sociocultural schools on understanding the processes of collective memory (Brescó \& Wagoner, 2015) and their linkage to collective action, imagination, and individual and social transformation (Zittoun \& Gillespie, 2015) may contribute in further developing the decolonial project.

\section{A Brief Background: A Toxic Environment}

Cultural psychology is well suited for studying disruptions and change (Valsiner, 2014; Cole, 1998). However, on the level of sociogenesis (Zittoun, 2019), the environment that structures Guarani and Kaiowá life-experiences in the reserves in Brazil's state Mato Grosso do Sul (MS) could appear as nearly static and suffocating. Movement is so slow that there are few signs of change. Here I define this material and symbolic reality as a toxic one, not only because of the pesticides applied in the agribusiness sector, poisoning 
the land, the air, and water resources but also because of the toxic patterns and effects of racism, colonialism, direct and structural forms of violence, and human alienation (Urt, 2016; Ioris, 2020). Numerous research reports document the history of dispossession in the region; it is beyond the scope of this study to add to this detailed work (Benites, 2012; Brand, 2004; Pereira, 2012; Pimentel, 2012a, b). Hence, I will concentrate on giving just enough information for the reader to imagine certain developments that are central to this article's arguments.

\section{Land Dispossessions}

The original populations in this region of Brazil were left in relative freedom by colonisers until the end of the nineteenth century, when the first agro-company, Cia Mate Laranjeira, was established and the federal Indian Protection Service (SPI) begun displacing Indigenous peoples from their lands to newly created reserves (Urt, 2016). The Guarani and Kaiowá people's gradual dispersion away from their ancestral forests has been described as sarambi (Chamorro, 2015), meaning 'dis-order' in the Guaraní language. Under the gradual development of the agribusiness order, where transnational and national capital and the Brazilian state's geopolitical interests colluded (Oliveira, 2016), Indigenous populations were both made invisible and envisaged as cheap labour for the plantations: the reserves were therefore established close to the new cities. However, many Guarani and Kaiowá families continued to seek return to home territories. During Brazil's Military Dictatorship (1964-1985), this could lead to detention and torture, as documented by the Truth Commission's report (Brasil, 2014). The new Constitution of 1988 guaranteed the return of the lands to Indigenous peoples through a land-demarcation process; however, in MS, plantation owners continue to profit from agro-industrial extraction on Indigenous lands. Most of the approximately 45,000 Guaraní and Kaiowá individuals still live in overpopulated reserves, generally in extremely precarious conditions, lacking the most basic human rights. These suffocating conditions have been analysed as an ongoing genocide (Naccache, 2019; Ioris et al., 2019). Many Guarani and Kaiowá families engage in multiple strategies to defend their cultural survival, often articulated through Aty Guasu, which is the General Assembly of Guarani and Kaiowá people. This includes moving back into their Tekoha, the ancestral lands now under the control of plantations, and creating land recovery/re-occupation camps (retomadas in Portuguese) (Benites, 2012). This subjects them to violent persecution and uncertainty, but many prefer it to existence in the reserves.

\section{Agribusiness and Clean-Energy Demands}

The agribusiness sector in MS developed following patterns of global emerging 'flex crops' and commodities (Borras et al., 2016), as well as national financial, statemaking, and geopolitical goals featured in the Brazilian version of the 'green revolution' (Oliveira, 2016). Through the 'March towards the West' from the 1940s onwards, cattle and soybean gradually expanded in MS (Urt, 2016). ProAlcool was a national public policy aiming for a transition from fossil-fuel based gasoline that gained momentum during the 1970s Military Dictatorship and brought sugarcane from highly exploitative plantations in NorthBrazil to many of the country's regions (Sauer et al., 2017). In MS, however, soybeans and cattle dominated until around 2000, when the Kyoto Protocol increased the global demand for clean energy, and 'flex-fuel' cars were introduced in Brazil (Porto-Gonçalves, 2008). From then, 'flex crops' of sugarcane (fuel, food) and corn/soybean (biodiesel, food, feed) 
expanded in MS, backed by extensive financial support from the national development bank BNDS, and investments from world-leading petroleum companies and food producers (Sauer et al., 2017; Wilkinson \& Herrera, 2010) such as Shell, Petrobras, Bunge, and Cargill. Brazil figures among the world's chief producers of agrofuel (ethanol fuel and biodiesel). These world-leading companies and investors, enjoying climate-friendly labelling and access to 'green' financial mechanisms, contribute to deforestation and GHG emissions and are silent yet omnipresent actors in the land conflicts. MS is now among the Brazilian states most affected by climate change, with increasing drought and heat, the backdrop of the devastating fires in this state's Pantanal wetlands that we witnessed in 2020 .

\section{Methodology}

This empirical study explores Guarani and Kaiowá study-participants' knowledge and goal-oriented practices of resistance confronted with 'green' economies and climate change, emphasising their enactment of collective memory as a tool in transformative processes ranging from microgenesis to sociogenesis (Zittoun \& Gillespie, 2015). I seek to contribute to expanding decolonial research on Indigenous knowledges about climate change by exploring how sociocultural perspectives on collective memory and imagination can help to explain what activates re-membering and re-humanisation processes. These questions came to me, as a non-Brazilian woman, in 2014/2015 when I spent 5 months in the region engaging in a collaborative project with the Landless Farmers Movement (MST) I found myself having to deal with feelings of profound alienation and toxicity, facing the violent conditions in this region, on a daily basis. People from MST introduced me to the Guarani and Kaiowá retomadas; with other individual members of the network Via Campesina and activists in the region, they have supported the research process in many ways. Importantly, before the onset of research, they presented me to regional leaders belonging to the Guarani and Kaiowá people's political representation, the Aty Guasu assembly. Presenting the objectives and methodology to them before the onset of research was done to pursue more ethical relationships of trust and transparency, and open up for their criticism, and even possible disapproval of my project.

\section{Data Construction}

The Guarani and Kaiowá participants' processes of collective meaning-making, re-membering, and imagination must be studied in the context in which they occur, making methodological pluralism (Jovchelovitch, 2019) crucial. My data derive from ethnographic methods combining individual and group interviews with fieldnotes from observations, conversations, and document analysis (Case et al., 2014). I followed political mobilisations, spiritual ceremonies, public hearings, and everyday life in reserves and retomadas and participated in ad hoc emergency activities when human rights violations occurred. Of particular significance was the participation in three agroecology workshops that brought together farmers, scholars, and indigenous participants, enabling me to study how re-membering also occurred through dialogues with others. Data construction drew on four visits of altogether 6 months, 2017-2019. 


\section{Research Setting}

I constructed this research process from Dourados, the region's biggest city, established in the 1950s to serve the growing agribusiness sector. With longer stays in Dourados, the city's toxicity became increasingly apparent. Extensive cultivation of genetically modified (GMO) soybean surrounds the city's borders. Families from the nearby Jaguapiru reserve come to do low-wage work, often shouted at or ignored as they move about in posh neighbourhoods. Less than $1 \mathrm{~km}$ from the city limits lie the Guarani and Kaiowá retomadas Nhu Verá I, II, and III: these are often attacked, the families' tents of black canvas burned, and people shot by rubber or even real bullets. Precarious material resources and safety among the solidarity networks limit the human rights work to support them. Researchers and journalists become persecuted subjects, living under safety measures and avoiding publicity. As a human rights worker who had previously lived in Dourados explained: 'The spark of living has gone out, and I cannot light it again'.

This precariousness also influenced my research. Many safety measures were aimed at protecting research participants', supporting networks' and friends' safety ( Moss et al., 2019). This included reducing movements to and from the reserves and the retomadas, leaving me with less independence to construct a well-planned and less messy (de SaintLaurent, 2018a) research process. While focusing mainly on the Te' ýikue Reserve in Caarapó municipality, and six adjacent retomadas; Kunumi Poty Vera, Namoy Guavira'y, Jeroky Guasu, Tey' Jusu, Guapo’y, and Itagui, I sought to make my research process more open and flexible. By responding to ad hoc necessities, which might be anything from delivering seeds to a retomada to helping with the documentation of human rights violations, assisting as a car driver, etc. I could approach other areas as well. Hence, research was also done in the retomada Laranjeira Nhanderu in Rio Brilhante municipality, in the Indigenous land Panambizinho, and in the reserves of Jaguapiru and Amambai, and in the retomadas Guyraroká and Guyrá Kambi'y. Interviews $(N=9)$ with public servants working in welfare institutions were conducted in the city of Dourados.

\section{Interviews}

Participants were recruited for interviews after establishing prior contact. Sometimes other researchers or people from the retomadas joined in, re-shaping interviews into dialogues with multiple participants, often sharing a warm Chimarrão drink in the early morning or a chilled Tereré when the sun was high and temperatures rising. Interviews were conducted on timber banks, in the comforting shadows of a tree or inside educational centres. The interviews in Dourados $(N=9)$ took place in institutional buildings, more convenient for participants. In advance, participants were told about the objectives of the study and their rights, and gave their informed consent. Interviews were recorded or written down. The individual $(N=15)$ and group (8) interviews ranged from 15 to $130 \mathrm{~min}$. Interviewing was conducted in Portuguese; when some collective interviews slipped into Guarani, parts of the narrative were translated. However, deeper meanings, perhaps untranslatable, may not have been captured.

Community dynamics sometimes subverted the possibility of following standard interview procedures, as individual interviews would transition into family interviews, and some participants would enter or leave the conversation during group interviews. People would propose questions additional to the interview guide. Such constant improvisation may concern researchers, as the 'messiness' challenges assumptions about scholarly 
precision (de Saint-Laurent, 2018a). However, I soon learned that this had not only a critical ethical aspect, providing internal transparency concerning the objectives of my visit: it also generated dynamics that opened for rich and diverse dialogues, and allowed for more careful reflection on the interview not as a neutral instrument, but as a social practice (Brinkmann, 2016). Ethnographic writing can place oppressed populations at increased risk if researchers fail to reflect sufficiently on what they can write about (Case et al., 2014). Given the lack of safety in this research setting, participants' names and which areas they speak from were anonymised; further issues as to what could be presented in this article were determined through careful reflection and conversation with researchers in the region and Guarani and Kaiowá activists.

\section{Data Analysis}

Collective memory conveys people's accounts of the past through rituals, social interaction, artefacts and text. Narratives help to give form and meaning to the past (Brescó de Luna, 2017) and are thus essentially political (Hammack, 2011). Fifteen individual interviews and eight group interviews in this study were transcribed (except on four occasions, where audio had not been recorded) and analysed. Through procedures from Thematic Analysis (Braun \& Clarke, 2006), I identified shared themes across accounts. I searched for both latent and semantic meanings (Braun \& Clarke, 2006), as meanings might not always be directly expressed. Nine interviews of public servants in welfare institutions were treated differently; except from one excerpt below, they are not presented in this study, but helped me understand the institutional entanglements of coloniality and the context in which study-participants' strategies unfold. As Kvale (1996) points out, the term 'transcript' may imply a reifying analysis that reduces meaning to 'verbal data'. The parallel reading of extensive fieldnotes helped me recall the interview situation, vital for exploring the original interview's meaning zone (Kvale, 1996). For outsiders, the web of meanings in a given community may be hard to interpret (Rogoff, 2003), and linguisticepistemic translation risks failing to capture, or may even erase, the depth in meanings (Vázquez, 2011). Aware of the possible epistemological fallacies of interpretation, I emphasise the dialogical aspect of this ethnographic study. The community narratives I identified may best be understood as a synthesis between the meanings carried by participants' accounts or practices, the research questions as an optic that zooms in on specific aspects of a narrative, and the culturally moulded tools researchers have for interpreting and creating meanings through these stories. Perhaps all qualitative research can be described as a dialogue between such different 'ways of seeing'. Nevertheless, in settings where coloniality is a concern, dialogical jargon about the interview can mask the further reproduction of power asymmetries (Kvale, 2002). Methodological-epistemological transparency and humility about possible misunderstandings are essential in pursuing valid and ethical research.

From my data analysis, I organised three main narratives: (a) disruption of freedom and abundance: 'The bird has no boss, nor a farm'; (b) from abundance to disease and suffocation: 'Disoriented as a dog when you're moving'; and (c) different paths to re-membering: 'When we return to our Tekoha, we are re-living our future.' 


\section{Findings}

\section{Disruption of Freedom and Abundance: 'The Bird has No Boss, Nor a Farm'}

Central in the participants' narratives were the timepoints when the Guarani and Kaiowá ways of life suffered disruptions, and the dismembering of their communities either started or deteriorated. These narratives were often presented together with reflections about the meaning of being Guarani and Kaiowá. Petrus, a man in his fifties, deeply involved in agroecology projects in several communities, summarised his understanding of the mission of the Guarani and Kaiowá on our planet:

O bem viver [living well], is when God made the earth, the forest, the water, the soil, the light and the stars, and there was no one to admire this work of God, right? So the Guarani and Kaiowá people were sent to admire it. They called us Yvy poty, flowers of the earth. (...) we came here to admire and celebrate it. And help in taking care of it too. Valuing, that is our role.

Through the term bem viver' (Spanish, buen vivir; in English 'wellbeing'/'living well') Petrus connects how he observes the Guarani and Kaiowá ways of life to an extensive decolonial and post-development literature developed from Latin American realities that promote models of sustainability and reciprocity learned from Indigenous cosmologies (Grosfoguel, 2016). Guarani equivalents to bem viver, like Teko Porã $\tilde{1}^{1}$ (enacting beauty/ good), Teko Joya (enacting reciprocity), and Teko Katu (enacting the person's abilities), were mentioned in many of the interviews. Guarani anthropologists explain that Teko means how one moves through a space (Benites \& Ramos, 2017). This could be translated as 'enacting', but also carries a normative value regulating individual behaviour. These positive 'Teko's' defined the Guarani and Kaiowá identity in opposition to the Karaí, a term today denoting white or non-indigenous persons, often with negative, clearly colonial connotations. Dandara, a woman in her twenties who is active in the youth movement, explains how her identity is shaped through involvement with the past, and in opposition to Karaí (white) society:

[The plantation owner] does not have Teko Rexai [health], Teko Joya [reciprocity], Teko Vy' $a$ [enacting and inspiring happiness]. Because he thinks about himself, does not consider us as humans: that we are alive, that we preserve (...). He does not have anything of what we have, all the Tekos that we have. We can say he is without a soul, without a heart. That's why he kills us. We have this spirituality, we respect a person even though he is bad. He does not. He is not concerned if we die of pesticides, or from a rubber bullet or a real bullet: he's not even there to witness it. So he does not have the Teko Mborayhu (enacting love) that we have so much of. The love for people, animals, nature, this is what we have and use, it was always like that (...). The ypy, the humans from past times, initiated all of what we have today; they made it very clear how we should live, what rules are there for us. So, we always have these rules about life and sustenance. So we do the Jerosy, which is the baptism of corn: all that we plant is blessed through [the spirit of] Jakaira. We plant and harvest what we need to live, for humans and animals. This is how we live.

\footnotetext{
1 I have read Mura (2006) and João (2011) for a tentative translation of the different 'Teko' in this article. Any inaccuracies in the translation are my responsibility.
} 
Arturo, a man in his fifties, explained how several signals appeared before the displacement of his family: 'First came the Fusca, then the Rural (a car model used in rural Brazil in between the 1950s and 1970s), then the cattle, and then the forests were cut down. Before I could think, I was in a chiqueiro (pigsty).' According to study-participants, 'the de-structuring', 'confinement', and 'crowding people together' severely disrupted the Guarani and Kaiowá 'good practices' and spirituality necessary for maintaining equilibrium in the cosmos, a responsibility that the cosmology and creational myths emplace on the Guarani and Kaiowá (Mura, 2010). Such practices cannot be conducted just anywhere: they must be done in the sacred areas where the families have historical ties.

The spiritual guide Dalia, with whom I spoke in a situation of uncertainty and tension but also of shared optimism in a small Tekoha that had been recovered only 14 days earlier, had, at the age of 94, returned to where she was born-after having spent most of her adult life living inside the reserves, and 11 years in a provisional camp near the BR-163 highway. She still remembered how she had been displaced 83 years earlier: 'Here is my land, I was born here. Here lived my father and mother. Now things will be better than before. We can breathe fresh air. We were massacred, and thrown into the map; they burned down our prayer house. Everything we had was burned.'

I believe that the 'map' reference in her account concerns how borders drawn into the map and fences are a fundamental aspect of the earlier-mentioned sarambi (Chamorro, 2015). The reserves were demarcated, so being 'thrown into the map' may mean being locked into the reserve, perhaps into the Karaí (white society) logic, or into the logics of agribusiness expansion (Sauer, 2018). Carlos, an energetic man in his 30s, told me, significantly: 'The bird has no boss, nor a field [roça]'. In the Guarani and Kaiowá cosmology, birds have deep meanings as guardians incorporated in the human body (João, 2011). Carlos shared his reflection as we were sitting by a fire one night after returning from an excursion to his family's ancestral lands, where he had helped as an interpreter in several interviews. It left me thinking. The boss-reference seemed an explicit criticism of exploitation and of the replacement of the Guarani and Kaiowá cosmologic-political system with the captains inside the reserves (Faria \& Martins, 2020). The field reference was more challenging: today, the roça/field is a space for growing food, for generating resilience and for recovering ancestral practices. This made the sentence look contradictory to me. Unable to reach Carlos while doing data analysis, I contacted Dandara through WhatsApp and asked what the sentence might have meant. She responded:

The bird does not have a boss, because he wakes up and does what he has to do. When he plants, I do not think he needs any payment. Birds eat fruit and spread the seed around, and their field is the whole world, right? The bird carries fruit, and the seed falls on the ground wherever it passes. He will not stay in only one place. (...) Another day, another bird will pass by the same place, and that one seed that the first bird left will grow, spring, and sustain other birds. So, the field is immensely big: it is the whole world. There is not one specific, unique place. It is like us. That's how our life is based as well, as Indigenous people.

Several participants mentioned 'freedom' and 'abundance' as lost through borders. Research describes the Guarani jeguatáloguatá ('the walk'/'to be walking') as a vital ethos in the long history of the Guarani peoples, connected to senses of freedom (Pimentel, 2012a, b). This freedom to move requires abundance, since when migrating people cannot carry their maintenance (Johnson \& Adoue, 2020). The bird in Dandaras 
account, moving freely and generating abundance for those who come in the future, seems to exemplify this connection. The movement to return to the Tekoha's can perhaps be seen as a resignification of jeguatá (Ibid, p. 229) in the contemporary context of agribusiness hegemony.

Lucia, a woman in her forties, explains the sin qua non of a fence: 'Everything you steal needs to be protected'. In a region where trees and forests have become rare, and the plantations frequently control the small, reserved forests, study participants spoke of their difficulties in fishing, hunting, and finding natural remedies. Michael explains the lived experience of these borders:

... we find a barrier in the border. Not the border with Paraguay; let us say the territorial border. The farm-owned forests. I cannot enter there, the farmers expel us, and they can even kill. They can enter the forest and cut down [trees]. But we cannot get [plant] medicine. This makes our daily life difficult.

The processes of destruction of the forests during the period of sarambi were an issue discussed by several participants. As Tomas explained in an interview:

In some places, the community destroyed the forest, demolishing, and cutting trees. But they did not realise that they were cutting down the remaining future for their grandchildren's family. That was psychologically so... He did not realise that he would suffer now (...). We did not make this loss of autonomy. The government made the mess.

Lucia observes in a similar pattern:

We were Kaigua, which means the 'forest people': now we are just called Kaiowá. We became dominated; we started to have confidence and trust in the Karaí (...). We felt secure, and that is when we gave away our world. Today, it is difficult to recover.

Her vision of what happened historically is then projected into her understanding of the current situation:

In this world, when things are at the most brutal, you continue doing what destroys, as if we were hitchhikers with no control over where we are going. The desires of the Karaí are big, like an incurable virus.

\section{From Abundance to Disease and Suffocation: 'Disoriented as a Dog When You're Moving'}

Sugarcane fields, or canaviais in Portuguese, enclose the Te' ýikue reserve and adjacent retomadas. These are operated by large farms, which today have possession of the claimed ancestral lands. The farmers deliver sugarcane to Raízen, a joint venture enterprise owned by the multinationals Shell and Cosan, and a leading biofuel producer. Over the years, the retomadas have repeatedly been targeted by threats and attacks, and during interviews the participants kept reminding me of how many Guarani and Kaiowá have lost their lives to pistoleiros, armed men, allegedly with links to neighbouring sugar plantations. During fieldwork in 2018, tensions rose in the wake of the presidential election, and several study participants received death threats. Distrust increased, particularly against white and nonindigenous people. For instance, if we were uncertain about the route while driving to certain communities, and stopped the car to ask a pedestrian, the chances were that we could be sent in the opposite direction, and suddenly end up lost in the canefield (canavial). 
Inside the canavial, labyrinths of paths create shortcuts from one area to the next, at times preferred over muddy and rocky roads, where vehicles risk getting stuck during the rainy season or to coming under surveillance. Farther south in the state, closer to the city of Naívirai, the canavial is an alternative to the use of BR-163 for pedestrians from the Indigenous communities, as fatal collisions pose additional dangers. But when the cane grows tall, pistol men or roaming youth gangs (see works of Morais, 2020) may hide there. Dina, a Nhandesy (spiritual guide, woman) and leader in a retomada, explains:

Here in Mato Grosso do Sul, we are very victimised and suffering. We can't even go to the city because it is dangerous. Nowadays, anything can happen if you go through the canavial . Look, just right there on the edge. (...) It looks all calm and quiet but at times... I ask everyone to try to stay awake and remain vigilant. They can only sleep around $3 \mathrm{am}$.

The sugarcane and soybean/corn flex crops pose other dangers to wildlife and humans. Health vulnerability through excessive use of pesticide received attention in MS in 2016, when a study showed that each individual consumed, through food and water, an average of $40 \mathrm{~L}$ of pesticide per year, against the national average of around 7 L (Douradosagora, 2016, 25/10). Guarani and Kaiowá reserves and camps are further exposed to continuous pulverisation of pesticides from tractors and small planes (Pignati et al., 2017). I was frequently told of toxic white clouds, blown by the wind towards the communities, producing diarrhoea, vomiting, confusion, headache, respiration problems, and psychological trauma. Sometimes the tractors or planes appeared so near schools or homes that they were understood as direct toxic attacks. As Michael put it:

Where is the United Nations? They always come when the dust has settled. We feel they push forward, and then they pull out again. (...) At least, they and the MPF [Federal Prosecutor's Office] could instruct us about what to do. No one defends us. While we sleep, we think, or we are awake, we can never rest.

Whereas soybean and corn cultivation employ few people, manual work is still required in the sugarcane plantations. During the harvest season, buses pick up men at 2 a.m. and return them at dawn. The work is hard; the wages are low, and their bodies tired. Cristian described his work in the nearby sugarcane plantations: 'It is like not getting enough air.' According to Thomas, the entry of sugarcane in the late 1990s exacerbated the 'de-structuring of the Kaiowá system'. During intensive harvest seasons, the families were separated for many months, when men left their homes for the plantations. In his view, this was how alcohol and drug abuse joined the line of problems facing people inside the reserves.

Study participants characterised the reserves' situation, as 'disorientation', 'confinement', 'confusion', like a 'persistent illness' or 'spiritual disease', produced by deforestation and the displacement of the Nhanderu and Nhandesy (male and female spiritual guides) from sacred places, causing miscommunication between them and God. Their prayers may be weakened, no longer able to maintain the cosmic equilibrium, with consequences felt on many levels, including the planetary level, through climate change, manifesting through fierce winds, drought, and heat in the region during this research. Guarani and Kaiowá participants spoke of the connection between the manifestations of disequilibrium or spiritual disease in the human psyche, and disequilibrium at the level of the family, the community, and eventually the whole planet. Disturbances on one level have consequences for the other levels and recovery strategies needed to target all levels. 
Locally, this spiritual disease may find an expression in the alarming waves of youth suicide in the reserves, and in alcohol-abuse related violence, that increased since the 1980s. For a long time, research and public discourses reproduced biases through attributing the high suicide-numbers among the Guarani and Kaiowá to anomalies or cultural traits (Pimentel, 2017, pp. 289-291). I noted how Maria, an administrator working in a network of institutions promoting Child Protection, interviewed in Dourados, termed the situation a 'disease', but her concept of disease was a different one, with little historical awareness:

At night, people are frightened. They do not walk around in the community because of the violence. Many people say, 'Ah, it's because of the land loss.' No. You can't blame it all on the fact that they do not have access to land. Today you need a whole [medical] intervention to treat almost everyone there.

Later in the interview, I asked what she thought about a common criticism voiced by study participants, that health and childcare institutions lack cultural awareness, she replied:

People say, 'Oh, you take culture away from them.' What culture? The children there are living in canvas tents (...) I went there myself, and you see there, what culture are they preserving? When you see reports from Amazonas, you see indigenous people doing those dances; there they have all their culture preserved in the community. It's different here.

Her words seem to fit in the discourse that Pimentel (2017, pp.304-305) identifies among the political elite in MS. In this, the Guarani and Kaiowá are blamed for their calamities. Dandara (quoted above: a woman active in the youth movement) differ, and reflects on the current situation as a form of torture:

People look around here. The psychological torture from agribusiness starts messing with our minds, with our community. People think we have no chance, that 'for me, there is no return': no more forests, no more birds, no longer that nice wind, because the trees are all gone. This process leads people to think that it is all over, it generates many conflicts in their minds and people ask themselves: 'will I ever be able to live, to live again the life I had before?'.

For Michael this agribusiness model even leads to a genocide:

Genocide is a set of things, making you lose your identity. The soybean plantations are a kind of genocide, because we can no longer plant what we had. Today, only sugarcane, soybean, and cattle. What you once had can no longer be born. That is why genocide is a set of things, identity, culture, and soil for growing. It is not only about killing as such. (...) Genocide does not hurt. When you begin feeling, it is too late. It all become unstructured ('desestructurado') and as a dog when you are moving; you feel, and become all lost.

Lucia also finds a connection between human disease and ecology, and claims the disease is not only affecting her own community: 'Today what rules is the ideology of dominating the rest, and all of us get sick.' She continues, 'This society that robs all, cuts everything down, with no compassion is a psychopathic society'. Dandara, reflecting on possible ways out, sets Indigenous practices in opposition to white, colonial 'ways':

First, we need to change how the latifundio (large plantations) work. Most polluters are among them, cutting down trees and planting much more than they should. 
(...) Nowhere will you find Indigenous people producing plastic, or petrol. Natural resources cannot recover anymore; they are extracted exaggeratedly, as with the mining. Then nature herself starts killing humanity. Nature wants to show that we will suffocate. Only today, experts started to talk about global warming. It started long ago, but they only discovered it now. Too late. But I think we can still prolong a while our survival.

\section{Different Paths to Re-Membering:'When we Return to our Tekoha, We are Re-living our Future'}

Onildo's words while we were walking to see an agroecology field were clear:

We bring together allied people and researchers who want to know how we are doing in the villages. Have we had only deaths, since nothing else is spoken about? In Dourados, it is when bad things happen that we are described in newspapers, right? A dead person, a beheading. That's how it goes. [It would be] better with, 'Ah look, the school, it's doing a great job, just look and see!' But no one speaks like that!

Whereas the two previous narratives point to how losses, disease, and dismemberment are entangled with climate change, this theme explores connections between the participants' collective memories and some of the strategies enacted to construct criticisms of the causes of climate change, to recover from trauma, to build resilience, and finally re-establish the cosmic equilibrium.

I noticed how elderly and front political figures would often begin narratives with 'In the old days...' ('Antigamente'). This seemed to be not only a dignifying act of a people's historical memory, but equally an insistence on the possibility of another way of living. The memory of earlier ways of life, still alive in older people's minds and passed on through stories and rituals, was central in the community initiatives and political actions I observed.

Similarly, Deborah, a youth assembly leader, reflected after our joint meeting with an elderly Nhanderu visiting the opening of a prayer house from another region in the state. She had looked amazed while speaking with him. I had been sitting close by, only offered little translation, and, from my perspective, noticing how his way of speaking had a melody to it that resembled the prayer chants. Returning to Dourados in the late afternoon, I asked her what had happened. She answered:

In the past, Indigenous psychology was a complete process. I am doing research, not for the university, but for myself: how to become stronger. It is a challenge to understand. To find the way of Teko Porã, to walk the right path. To achieve that, which is difficult, you need to be humble and good; that process exists for us Indigenous people also. He told me the whole story, the cosmology, why that bird always sings. But writing it down in Portuguese will be tough. The Nhanderu speaks in an ancient language; even I need to pay close attention.

\section{Recovering Through the Roça}

'Agroecology' is a recent word in Guarani and Kaiowá communities, but historically, growing food through particular agricultural practices has been vital, not only for food 
self-sufficiency but also according to study participants, closely connected to spiritual rituals. Confinement in reserves prevents proper care of the soil. In the retomadas, reviving the practice of caring for the soil was a fundamental and yet demanding task because of the little space, the poisoning of the soil, and the loss of seed varieties. Research has noted the importance of agroecology for climate change mitigation, resilience, and trauma work (Einbinder \& Morales, 2020; Rosset et al., 2011). In my research setting, agroecology had also become a space for meaningful dialogue, involving exchange of knowledge and seeds with people from other communities, and ranging from university personnel to missionaries and members of the global peasant network Via Campesina, which has long advocated a political version of agroecology. As Marvin, an experienced agroecology promotor in his 30 s, reflected:

It is a challenge to recover and to create more happy persons again. Health and emotions; we need to approach that again, recuperate it. So, when we speak about the practice of cultivating; In the past, it was a recreation, right? It was not work; it was leisure. (...) As the activities developed, you made fun, you sang. You did not have to keep an eye on the clock. When it was cold, you started a bit later. When it was warm, you finished sooner.

The idea is now to recover Guarani and Kaiowá knowledge-'What we always knew but were unaware of,' according to Petrus. The central idea is to plant consortiums of different plants that mutually support each other and protect the soil. Further, this diversity of seeds and plants seemed to be engendering small 'cracks' in the imaginary of monocultures promoted by the agribusiness hegemony. David, a non-indigenous missionary who was participating in the workshops, reflected:

For some time, I found the soybean fields aesthetically beautiful. I saw a lost tree in the middle of it. I found it pretty. But there is no beauty in that! Now I have taken deliberate steps away from understanding that monotony as pretty. But we are culturally educated to find beauty in monotony, practised on a large scale by the dominant system.

Participants noted the importance of including rituals and spiritual guidance from the Nhandesy and Nhanderu in combination with the kind of techniques mentioned above to cure not only the soil but also the people. Martin, a young assistant teacher in the practice of agroecology, referred what the local Nhanedsy had told him: 'Mari explains that when you participate, you also need to dance Guaxiré, then you have a higher chance of cutting off that pain and the feelings related to the bad spirits, you scare it out of yourself.'

However, Genaro, nearly 100 years old at the time of our conversation, pointed to how the lack of land had forced individualist behaviour patterns upon people, and that reviving the reciprocity of earlier times might be difficult. Many practices seemed to be aimed at not making matters worse. All living entities or natural phenomena have, according to Guarani and Kaiowá cosmology, specific kinds of Jaras/Járys, or spirits/guardians (João, 2011; Mura, 2006). When humans cause destruction or stop following specific behaviour norms, these Jaras may abandon the Earth, causing the disequilibrium that in Western thought is understood as climate change. Lalo, a Nhanderu, held that the high winds and extreme drought announced the forest Jara's abandonment. But according to him, the Jara of agriculture and the Jara of the Earth were still here, and so efforts are made to keep them around and prevent famine. 


\section{Imagining the Future}

At one point during fieldwork, when reflecting on the position of memory in a context where agribusiness has penetrated ways of life so thoroughly, I found myself sitting around a fire late at night in a retomada. I had come there to attend a political meeting the next day, where the murder of a young health worker and his father's incarceration 3 years earlier would be remembered. A Kaiowá friend in his early twenties asked me, with a big smile, 'how do you imagine the future?' Impressed by the fact that I had been asked one of the questions I was trying to deal with in my research, and where people often seemed reluctant or shy about answering, I replied as I best could; and was, unfortunately, hindered from asking him. A French anthropologist, doing an ethnography in the area, was sitting next to us and had picked up elements of the conversation. He asked me fascinated, 'Did he tell you about his view on the future? You must hear his answer!' Without knowing it, he was getting close to one of my research puzzles. The next day, we had gathered where the friend had been killed 3 years ago and was now buried. The Brazilian flag placed on the grave was flying; it had holes in it, and red paint, symbolising the shed blood. Around us there was high pasture, growing again after the land area had been recovered three years ago; then, some $500 \mathrm{~m}$ down a gentle slope, the rows of sugarcane commenced. At the community's request, I was filming the event, where the community leaders, one by one, shared their words, meant to fly far, meant to make a difference in the hearts and minds of other peoples. The friend from the fireplace the previous night was leading the ceremony. Suddenly in a well-formulated and energetic political discourse, he said, 'Our future is not there in front of us. Our future is behind us. When we return to our Tekoha, we are re-living our future.'

\section{Discussion}

'Narratives' can be people's accounts of disruptions in the expected course of things, about meanings that are given to them, and about attempts to resolve the unexpected (Bruner, 2008). Narrative knowledge involves efforts to search for plausibility and coherence (Polkinghorne, 1988) and can set in motion human actions (Brockmeier, 2009). In my study I have found that through narratives built on different forms of memory, the participants constructed strong criticisms of the modernity/coloniality models of progress (in their words, Karaí ways of being) that are dependent on extractivism. Study participants did not decouple coloniality/modernity from climate change-neither in addressing causality nor in enacting resilience strategies. This is perhaps no surprise, given the collective memories of how initial contact with white colonisers concurred with the deforestation and destruction of their world system.

In light of these findings, the United Nations' recent calls to include Indigenous knowledge (IK) in climate agendas have become a thought-provoking and complex matter. As this study has shown, Indigenous knowledges can entail profound breaks with central logics of the current climate agenda that promotes models of green growth, with agrofuel-production (not least in this specific research setting) expanding despite the increasing global focus on land-use change as a significant cause of harmful emissions (IPBES, 2019).

Grosfoguel warns how Western systems can extract, de-politicise, and decontextualise artefacts, objects, and knowledges—re-signifying and assimilating them into Western-hegemonic 
ways of being (Grosfoguel, 2016). An example of this, relevant in the research setting, is how some companies in the agribusiness sector in the region now frame parts of their endeavours as 'agroecology', through limited technical fixes, all the while ignoring the sociocultural, political, and in this research setting deeply spiritual meanings of agroecology. Such 'greenwashing' or 'co-opting' practices (Giraldo \& Rosset, 2018) may indicate that underlying the de-politicisation of IK identified by Grosfoguel, there can be disputes concerning people's ability to imagine other futures. This draws our attention to political imagination. My findings are in line with research that has explored the function of collective memory to processes of political imagination (de Saint-Laurent, 2018b). Through narratives by spiritual guides and other elderly individuals, the constant practice of remembrance 'speak to' youth and children who grew up in colonial and adverse situations. The narratives of how things were before seemed to indicate conscious efforts to open the ability of children (and adults) to imagine other possible futures - but also to connect their experience with a different past, one without 'disease', and thus to contest stereotyped accounts of them. I found that, rather than implying nostalgic mourning of any kind of glorious past, remembrance enabled critical engagement with the past (de Luna, 2018): demystifying agribusiness hegemony, defining causations, and constructing imaginations of possible collective futures (Melià, 2015) that became a central tool in collective enactments. Kaiowá anthropologist Benites (2020, p. 20) describes the search for a future in the past as to follow existing elements (rivers, prayers, forests, practices) as 'conductive lines to the past and spiritual dimensions, and when returning, bringing back the living memory to fundament new relations in a constantly transforming reality.'

In a way, the Guarani and Kaiowá participants' efforts to re-member their communities (and by extension, the cosmos) have the dual purpose of casa adentro and casa afuera, as expressed by Juan García Salazar (In Mignolo \& Walsh, 2018). Casa adentro (in house) is the re-memberment through re-connecting young people with the collective memory, and casa afuera (out of house) may denote the dialogues with 'others.' Among Guarani and Kaiowá communities there are ongoing efforts at undertaking such dialogues, with other Indigenous peoples, but also with possible allied individuals in the Karaí system, through invitations to register (and spread the word) of ceremonies, to contribute in processes of agroecology, or to receive researchers like myself. These dialogues may move us closer to the Guarani and Kaiowá notion of nhe'e, meaning simultaneously word, language, and soul. Nhe'e, is sacred (Cariaga, 2019), both during dialogues and during when stories are shared (João, 2011). Gonzalez and Silva Guimarães (2020), working in the Mbya Guarani context, propose that nhe'e might be an equivalent to the western word psyche. This is not to say that the worldviews are similar, but to underline how psychologists, in order to overcome epistemic violence, may seek to engage dialogically with the conceptions in the communities in which they study, instead of homogenising translation efforts. In this way, narratives, or nhe'e, can present us with possibilities of imagining the world (and ourselves) from another's viewpoint, gaining new senses about what things are about (Bradbury, 2019). They open for the possibility of imaginatively moving forward into 'what if' futures (Andrews, 2014 as cited in Bradbury, 2019 p. 100). Against this backdrop, the dialogic engagement with the meaning system of the Guarani and Kaiowá during this research project also opened a critical bifocality (Weis \& Fine, 2012), redirecting the gaze away from victimisation narratives towards a critique of both the shortcomings of psychological science in this study setting, but even further, towards imagining other ways of being in Western settings.

In a time when the re-prefix finds its way into research and public discourses concerning climate change, the Guarani and Kaiowá strategies may not be read as static or essentialised cultural features. Minds and cultures are in constant movement, and sociocultural history provides communities with a material and a symbolic basis for possible epistemological locations (de Sousa Santos, 2014 see also; Zittoun, 2019) that allow participants to develop profound 
critiques of coloniality. Their method for theorisation has resemblance with the anticolonial work of Frantz Fanon, who, through the embodied experience and phenomenological writing about being a black man in colonial Martinique, developed his ideas of the sociogenesis of racism (Fanon, 2017; Bulhan, 1985). Similarly, the study participants developed decolonial ecological theory, generated from their experiences of deforestation and dismemberment and projected to today's global challenges. Through this, they could target various strategies of re-membering and resilience-on the micro-, meso-, and macro-levels-interconnected with their cosmology. One example is agroecology; it had healing effects on individual and community traumas. It was directed at increasing resilience in the retomadas. It enabled the elderly to strengthen spiritual work - and it meant dialogues with other communities and questioning agribusiness hegemonies at the macro-level.

Such models of personhood and social relations can be critically important not only for Indigenous communities but also as models that better suit humanity's interests in Western settings (Adams et al., 2018b). Indeed, some communities may now be figuring as laboratories as they resist and generate resilience under extremely adverse conditions (EGSVL, 2019): here, the case of the Guarani and Kaiowá can be seen as one such place. In the broadest sense, the toxic environment in which they live is a dystopic image of some of the unsolved problems in models of green economies. In another sense, their persistent efforts at defending a collective memory can pave the way for re-thinking also in Western academic institutions. In these institutions, contemporary aspirations to re-think, remake and recover, as well as sociocultural psychology's search to understand possibilities and limitations of human imagination, can perhaps partially be explained by increasing exhaustion (de Luna, 2018), and the paradigm shift in how we think about the future that Mbembe (2019a, b)observes. Western future-oriented optimism is becoming replaced with dissonance and social retreat (Morselli, 2013), as fires and floods with planetary consequences force us to recognise our strategies' failure. One contribution from sociocultural and decolonial researchers might be to engage more deeply in accompanying individuals and communities to enact collective re-memberment and imagination processes.

\section{Conclusions}

This study has drawn on a loose conceptual framework, combining sociocultural psychological work on collective memory, political imagination, and human action with the concept of re-membering in decolonial thought. This framework, taken together with the narratives shared in this dialogically oriented study, enabled exploration of how the Guaraní and Kaiowá participants' collective memory became a fundamental tool for imagining and enacting on the future. Collective memory further allowed study participants to articulate profound criticisms of the toxic environment that prioritised agrofuels and green growth-paradoxically, among Brazil's commitments to the Paris Agreements.

However, the study is not exhaustive. Language limitations and colonial entanglements continue to mark academic practices and knowledge production. Therefore, the concept of dialogue is less about promoting a kind of normative or resolved 'positive practice', and more about being transparent about research as a social practice where new meanings are constructed-also when a researcher from 'the outside' may misinterpret complex meaning systems (Rogoff, 2003). In colonial systems, this practice has already produced much epistemological violence (Teo, 2010). However - and following Bradbury (2019)—in order to imagine new worlds, we all, including scholars, need to engage in dialogues with each other, with caution, respect and openness. Mignolo and Walsh (2018) pose this as 'thinking with', instead of 
'researching about'. The profound criticisms of the Karaí system voiced by the participants in this study have led to think that, even given these unsolved tensions, this admittedly modest and limited study makes a valid contribution to re-thinking hegemonic practices regarding climate change mitigation.

This is not to romanticise the adverse situation of the Guarani and Kaiowá. In 2019, during my last fieldwork, climate change was evident through extreme heat, and low rainfall. The Nhanderu and Nhandesy were praying for rain; I was told they were engaging in communicating with God to understand climate change better. Many agroecology fields dried up in this period, and soybean producers pressured communities to surrender their land for small fees. Some leaders accepted, generating turmoil in the local communities. A year later, the last forests in MS in the Pantanal wetlands some hours' drive north of the Guarani and Kaiowá ancestral lands were in flames, with footage of burned pumas broadcast worldwide. Indeed, such sceneries will multiply around the planet in the coming years, underscoring the urgency for scholars to work on many levels to support healing processes of re-memberment and re-humanisation.

Funding Open access funding provided by University of Oslo (incl Oslo University Hospital).

Acknowledgement First, I thank all the Guarani and Kaiowá participants for your openness and patience. Second, the researchers and activists in Mato Grosso do Sul who supported this research in multiple ways. Third, Nora Sveaass, Mariel Aguilar-Støen, Tanja Winther, Felipe Mattos Johnson, and the reviewers for your constructive comments that helped improve this article.

Open Access This article is licensed under a Creative Commons Attribution 4.0 International License, which permits use, sharing, adaptation, distribution and reproduction in any medium or format, as long as you give appropriate credit to the original author(s) and the source, provide a link to the Creative Commons licence, and indicate if changes were made. The images or other third party material in this article are included in the article's Creative Commons licence, unless indicated otherwise in a credit line to the material. If material is not included in the article's Creative Commons licence and your intended use is not permitted by statutory regulation or exceeds the permitted use, you will need to obtain permission directly from the copyright holder. To view a copy of this licence, visit http://creativecommons.org/licenses/by/4.0/.

\section{References}

Adams, G., Estrada-Villalta, S., \& Gómez Ordóñez, L. H. (2018). The modernity/coloniality of being Hegemonic psychology as intercultural relations. International Journal of Intercultural Relations, 62(13), 22. https://doi.org/10.1016/j.ijintrel.2017.06.006.

Adams, G., Kurtiş, T., Ordóñez, L. G., Molina, L. E., \& Oropeza, I. D. (2018). Decolonising knowledge in hegemonic psychological science. In N. N. Wane \& K. L. Todd (Eds.), Decolonial pedagogy: Examining sites of resistance, resurgence, and renewal (pp. 35-53). Basingstoke: Palgrave Mcmillan.

Afuape, T. (2011). Power, resistance and liberation in therapy with survivors of trauma: to have our hearts broken. London: Routledge.

Ajani, E., Mgbenka, R., \& Okeke, M. (2013). Use of indigenous knowledge as a strategy for climate change adaptation among farmers in sub-Saharan Africa: implications for policy. Asian Journal of Agricultural Extension, Economics \& Sociology, 2(1), 23-40. https://doi.org/10.9734/AJAEES/ 2013/1856.

Alphen, Fv., \& Normann, S. (Eds.). (2020). Cultural psychology in communities: tensions and transformations. Charlotte, NC: Information Age Publishing Inc.

Andrews, M. (2014). Narrative imagination and everyday life. Oxford: Oxford University Press.

Benites, E. (2020). Tekoha Ñeropu'ã: Aldeia que se levanta [Tekoha Ñeropu'ã: indian village that get's up]. Revista Nera, 23(52), 19-38. https://revista.fct.unesp.br/index.php/nera/article/viewFile/7187/5307 
Benites, E., \& Ramos, A. D. (2017). El camino Guarani y Kaiowá en la busqueda por la manera sagrada de ser-oguata teko araguyje rehehápe [The Guarani and Kaiowa walk to search for the sacred way of being- oguata teko araguyje rehehápe]. Revista Euroamericana de Antropología(4), 30-35.https:// gredos.usal.es/bitstream/handle/10366/141948/El_camino_guarani_y_kaiowa_en_la_busqued. pdf? sequence $=1$

Benites, T. (2012). Trajetória de luta árdua da articulação das lideranças Guarani e Kaiowá para recuperar os seus territórios tradicionais tekoha guasu [The trajectory of the hard struggle to articulate the Guarani and Kaiowá leadership to recover their traditional territories tekoha guasu]. RAU-Revista de Antropologia da UFSCAR, 4(02), 165-174. http://www.rau.ufscar.br/wp-content/uploads/2015/05/vol4no2_ 10.TONICO.pdf

Bhatia, S., \& Priya, K. R. (2018). Decolonising culture: Euro-American psychology and the shaping of neoliberal selves in India. Theory \& Psychology, 28(5), 645-668. https://doi.org/10.1177/ 0959354318791315.

Borras, S. M., Jr., Franco, J. C., Isakson, S. R., Levidow, L., \& Vervest, P. (2016). The rise of flex crops and commodities: implications for research. The Journal of Peasant Studies, 43(1), 93-115. https://doi. org/10.1080/03066150.2015.1036417.

Bradbury, J. (2019). Narrative psychology and Vygotsky in dialogue: changing subjects. London: Routledge.

Brand, A. (2004). Os complexos caminhos da luta pela terra entre os Kaiowá e Guarani no MS [The complex walks of the struggle for land of the Kaiowá and Guarani in MS]. Tellus, 137-150. https://doi. org/10.20435/tellus.v0i6.82.

Brasil (2014). Relatório da Comissão Nacional da Verdade. Texto 5: Violações de direitos humanos dos povos indígenas[Report from the national truth commission. Text 5: violations of Indigenous peoples' human rigts]. http://comissaodaverdade.al.sp.gov.br/relatorio/tomo-i/downloads/I_Tomo_Parte_ 2_Violacoes-aos-direitos-dos-povos-indigenas.pdf

Braun, V., \& Clarke, V. (2006). Using thematic analysis in psychology. Qualitative Research in Psychology, 3(2), 77-101. https://doi.org/10.1191/1478088706qp063oa.

Brescó de Luna, I. (2017). The end into the beginning: prolepsis and the reconstruction of the collective past. Culture \& Psychology, 23(2), 280-294. https://doi.org/10.1177/1354067X17695761.

Brescó, I., \& Wagoner, B. (2015). Context in the cultural psychology of remembering. In C. Stone \& L. Bietti (Eds.), Contextualising human memory: an interdisciplinary approach to understanding how individuals and groups remember the past (pp. 69-85). London: Routledge.

Brinkmann, S. (2016). Methodological breaching experiments: steps toward theorising the qualitative interview. Culture \& Psychology, 22(4), 520-533. https://doi.org/10.1177/1354067X16650816.

Brockmeier, J. (2002). Remembering and forgetting: narrative as cultural memory. Culture \& Psychology, 8(1), 15-43. https://doi.org/10.1177/1354067X0281002.

Brockmeier, J. (2009). Reaching for meaning: Human agency and the narrative imagination. Theory \& Psychology, 19(2), 213-233. https://doi.org/10.1177/0959354309103540.

Bruner, J. (2008). Culture and mind: their fruitful incommensurability. Ethos, 36(1), 29-45. https://doi.org/10. 1111/j.1548-1352.2008.00002.x.

Bueno-Hansen, P. (2018). Decolonial re/membering through collective lesbian embodiment at Villa Grimaldi. International Feminist Journal of Politics, 20(1), 91-94. https://doi.org/10.1080/14616742.2017. 1385183.

Bulhan, H. A. (1985). Frantz Fanon and the psychology of oppression. New York: Plenum Press.

Cariaga, D. E. (2019). Relações e diferenças: A ação política kaiowá e suas partes. [Relations and differences: the political action among the Kaiowá and their elements]. (Doctoral dissertation, Federal University of Santa Catarina, Brazil). https://repositorio.ufsc.br/bitstream/handle/123456789/204486/ PASO0494-T.pdf?sequence $=-1 \&$ is Allowed=y

Case, A. D., Todd, N. R., \& Kral, M. J. (2014). Ethnography in community psychology: promises and tensions. American Journal of Community Psychology, 54(1-2), 60-71. https://doi.org/10.1007/s10464014-9648-0.

Chamorro, G. (2015). História Kaiowa: Das origens aos desafios contemporâneos [Kaiowá history:from the origins to contemporary challengues]. Bernando do Campo, SP, Brazil: Nhanduti Editora.

Cole, M. (1998). Cultural psychology: A once and future discipline. Cambridge, MA: Harvard University Press.

de Luna, I. B. (2018). Imagining collective futures in time: prolepsis and the regimes of historicity. In C. de Saint-Laurent, S. Obradović, \& K. Carriere (Eds.), Imagining Collective Futures (pp. 109-128). London: Palgrave Macmillan.

de Saint-Laurent, C. (2018a). Staying on topic: doing research between improvisation and systematisation. In C. Wegener, N. Meier, \& E. Maslo (Eds.), Cultivating creativity in methodology and research: In praise of detours (pp. 143-152). Basingstoke: Palgrave Macmillan. 
de Saint-Laurent, C. (2018b). Thinking through time: from collective memories to collective futures. In C. de Saint-Laurent, S. Obradović, \& K. Carriere (Eds.), Imagining collective futures: Perspectives from social, cultural, and political psychology (pp. 59-81). London: Palgrave Macmillan.

de Sousa Santos, B. (2014). Epistemologies of the South: justice against epistemicide. Boulder: Paradigm Publisher.

Dictionary, O. E. (n.d.). Remember. Online Etimology Dictionary. https://www.etymonline.com.

Douradosagora (2016,25/10). Consumo de agrotóxicoé de até 40 litros/pessoa; MS revêlegislação [Consumption of pesticides reaches 40 litres per person; MS revise legislation]. https://www.douradosagora. com.br/noticias/cidades/consumo-de-agrotoxico-e-de-ate-40-litros-pessoa-ms-reve-legislacao.

EGSVL, (2019, December 30 ). Life futures and the future of reason. [Video]. YouTube. https://www.youtube. com/watch?v=uv11y10XaLY

Einbinder, N., \& Morales, H. (2020). Development from within: agroecology and the quest for utziil k'asleem in the Maya-Achí territory of Guatemala. Journal of Latin American Geography, 19(3), 133-158. https://doi.org/10.1353/lag.2020.0074.

Fanon, F. (2017). Black skin, white masks. London: Pluto Press (Original publication 1967).

Faria, L. L. d., \& Martins, C. P. (2020). Colonial borders, liberation psychology and indigenous disobedience. Psicologia para América Latina(33), 33-42. http://pepsic.bvsalud.org/pdf/psilat/n33/ a05n33.pdf

Federici, S., \& Linebaugh, P. (2018). Re-enchanting the World: feminism and the politics of the commons. Oakland, CA: PM Press.

Fine, M., \& Torre, M. E. (2004). Re-membering exclusions: participatory action research in public institutions. Qualitative Research in Psychology, 1(1), 15-37. https://doi.org/10.1191/1478088704qp003oa.

Giraldo, O. F., \& Rosset, P. M. (2018). Agroecology as a territory in dispute: between institutionality and social movements. The Journal of Peasant Studies, 45(3), 545-564. https://doi.org/10.1080/03066150. 2017.1353496.

Glăveanu, V. P., \& Sierra, Z. (2015). Creativity and epistemologies of the South. Culture \& Psychology, 21(3), 340-358. https://doi.org/10.1177/1354067X15601196.

Gonzalez, R., \& Silva Guimarães, D. (2020). For a knowledge with the other in psychological science. Theory \& Psychology, 30(3), 419-424. https://doi.org/10.1177/0959354320927086.

Grosfoguel, R. (2016). Del extractivismo económico al extractivismo epistémico y ontológico. Revista Internacional de Comunicación y Desarrollo, 1(4). https://doi.org/10.15304/ricd.1.4.3295.

Hammack, P. L. (2011). Narrative and the politics of meaning. Narrative Inquiry, 21(2), 311-318. https:// doi.org/10.1075/ni.21.2.09ham.

Ioris, A. A. R. (2020). Indigeneity and political economy: Class and ethnicity of the Guarani-Kaiowa. Capital \& Class. https://doi.org/10.1177/0309816820959828.

Ioris, A. A. R., Benites, T., \& Goettert, J. D. (2019). Challenges and contribution of indigenous geography: Learning with and for the Kaiowa-Guarani of South America. Geoforum, 102, 137-141. https://doi. org/10.1016/j.geoforum.2019.03.023.

IPBES. (2019). The Global assessment report on biodiversity and ecosystem services of the Intergovernmental Science-Policy Platform on Biodiversity and Ecosystem Services. https://ipbes.net/globalassessment

IPCC. (2019). Climate Change and Land: an IPCC special report on climate change, desertification, land degradation, sustainable land management, food security, and greenhouse gas fluxes in terrestrial ecosystems. https://www.ipcc.ch/srccl/

Jepson, P. (2019). Recoverable Earth: a twenty-first century environmental narrative. Ambio, 48(2), 123130. https://doi.org/10.1007/s13280-018-1065-4.

João, I. (2011). Jakaira reko nheypyrũ marangatu mborahéi: Origem e fundamentos do canto ritual jerosy puku entre os Kaiowá de Panambi, Panambizinho e Sucuri'y, Mato Grosso do Sul. (Master's thesis, Federal University of Grande Dourados, Dourados, Brazil). https://www.ppghufgd.com/wp-content/ uploads/2017/06/Izaque-Jo\%c3\%a3o.pdf

Johnson, F. \& Adoue, S.B. (2020). Retomadas Guarani e Kaiowá: O socialismo indo-americano e a busca da terra sem mal. In J. H. Okumura (Ed.), Espectros de Mariátegui na América Latina. Marilia, SP: Editora Lutas anticapital.

Jovanović, G. (2019). The repression of cultural psychology in the history of psychology. In G. Jovanović, L. Allolio-Näcke, \& C. Ratner (Eds.), The Challenges of Cultural Psychology: Historical legacies and future responsibilities (pp. 169-186). London: Routledge.

Jovchelovitch, S. (2019). Discourse and representation: A comment on Batel and Castro 'Re-opening the dialogue between the theory of social representations and discursive psychology.' British Journal of Social Psychology, 58(2), 415-422. https://doi.org/10.1111/bjso.12296. 
Jovchelovitch, S., \& Hawlina, H. (2018). Utopias and world-making: Time, transformation and the collective imagination. In C. de Saint-Laurent, S. Obradović, \& C. K (Eds.), Imagining collective futures (pp. 129-151). London: Palgrave Mcmillan.

Kalafatic, C. (2020). Indigenous peoples re-membering their futures in extraordinary times. Development, 63(1), 27-30. https://doi.org/10.1057/s41301-020-00238-0.

Kvale, S. (1996). Interviews: An Introduction to Qualitative Research Inquiry. Thousand Oaks, CA: Sage.

Kvale, S. (2002). Dialogue as oppression and interview research. In Nordic Educational Research Association Conference Tallinn. https://psy.au.dk/fileadmin/Psykologi/Forskning/Kvalitativ_metodeudvikling/ NB32/dialogueopptallinnNB.pdf

Lima, M., Mendes, L., Mothé, G., Linhares, F., de Castro, M., da Silva, M., et al. (2020). Renewable energy in reducing greenhouse gas emissions: Reaching the goals of the Paris agreement in Brazil. Environmental Development, 33, 100504. https://doi.org/10.1016/j.envdev.2020.100504.

Maldonado-Torres, N. (2017). Frantz Fanon and the decolonial turn in psychology: From modern/colonial methods to the decolonial attitude. South African Journal of Psychology, 47(4), 432-441. https://doi. org/10.1177/0081246317737918.

Martín-Baró, I. (1994). Writings for a liberation psychology. Cambridge, MA: Harvard University Press.

Mbembe, A. (2019a). Bodies as borders. From the European South(4), 5-18. http://europeansouth. postcolonialitalia.it/journal/2019-4/2.Mbembe.pdf

Mbembe, A. (2019b). Necropolitics. Durham, NC: Duke University Press.

Melià, B. (2015). El buen vivir se aprende. [One learn to generate wellbeing] Sinéctica, (45), 1-12. http:// www.scielo.org.mx/scielo.php?script=sci_arttext\&pid=S1665-109X2015000200010

Mignolo, W. D., \& Walsh, C. E. (2018). On decoloniality: Concepts, analytics, praxis. Durham, NC: Duke University Press.

Morais, B. M. (2020). Do corpo ao pó: Crônicas da territorialidade Kaiowa e Guarani nas adjacências da morte [From body to dust:chronicles of Kaiowa and Guarani territoriality in the vicinity of death]. São Paulo, Brazil: Editora Elefante.

Morselli, D. (2013). The olive tree effect: Future time perspective when the future is uncertain. Culture \& Psychology, 19(3), 305-322. https://doi.org/10.1177/1354067X13489319.

Moss, S. M., Uluğ, Ö. M., \& Acar, Y. G. (2019). Doing research in conflict contexts: Practical and ethical challenges for researchers when conducting fieldwork. Peace and Conflict: Journal of Peace Psychology, 25(1), 86-99. https://doi.org/10.1037/pac0000334.

Mura, F. (2006). À Procura do bom viver: Território, tradição de conhecimento e ecologia doméstica entre os Kaiowá [Searching for well-being: territory, tradition of knowledge and domestic ecology among the Kaiowá]. (Doctoral dissertation, Federal University of Rio de Janeiro, Rio de Janeiro, Brazil). http://www.aba.abant.org.br/administrator/product/files/128_00163894.pdf

Mura, F. (2010). A trajetória dos chiru na construção da tradição de conhecimento Kaiowa[The trajectory of the chiru em the construction of the tradition of Kaiowa knowledge]. Mana, 16, 123-150. https://doi. org/10.1590/S0104-93132010000100006.

Naccache, G. (2019). Genocide and settler colonialism: How a Lemkinian concept of genocide informs our understanding of the ongoing situation of the Guarani Kaiowá in Mato Grosso do Sul, Brazil. In J. Bachman (Ed.), Cultural Genocide: Law, politics, and global manifestations (pp. 118-139). London: Routledge.

Ndlovu-Gatsheni, S. J. (2020). Decolonisation, development and knowledge in Africa: Turning over a New Leaf. London: Routledge.

Ndlovu-Gatsheni, S. J. (2015). Decoloniality as the future of Africa. History Compass, 13(10), 485-496. https:// doi.org/10.1111/hic3.12264.

Ndlovu, M. (2014). Why indigenous knowledges in the 21st century? A decolonial turn. Yesterday and Today, (11), 84-98. http://www.scielo.org.za/scielo.php?script=sci_arttext\&pid=S2223-03862014000100006

Newell, P., \& Taylor, O. (2020). Fiddling while the planet burns? COP25 in perspective. Globalizations, 17(4), 580-592. https://doi.org/10.1080/14747731.2020.1726127.

Nyong, A., Adesina, F., \& Elasha, B. O. (2007). The value of indigenous knowledge in climate change mitigation and adaptation strategies in the African Sahel. Mitigation and adaptation strategies for global change, 12(5), 787-797. https://doi.org/10.1007/s11027-007-9099-0.

Oliveira, G. (2016). The geopolitics of Brazilian soybeans. The Journal of Peasant Studies, 43(2), 348-372. https://doi.org/10.1080/03066150.2014.992337.

Pereira, L. M. (2012). Expropriação dos territórios Kaiowá e Guarani: Implicações nos processos de reprodução social e sentidos atribuídos às ações para reaver territórios-tekoharã[Expropriation of the Kaiowá and Guarani territories: implications for social reproduction processes and the meaning of actions to revive territories- tekoharã]. Revista de Antropologia da UFSCar, 4(2), 124-133. http:// www.rau.ufscar.br/wp-content/uploads/2015/05/vol4no2_07.LEVI_.pdf 
Pickren, W. E. (2018a). Light through a cultural lens: Decolonising the history of psychology and resilience. In G. Jovanovic, L. Nacke-Allolio, \& C. Ratner (Eds.), The challenges of cultural psychology: Historical legacies and future responsibilities (pp. 220-236). London: Routledge.

Pickren, W. E. (2018b). Psychology in the social imaginary of neoliberalism: Critique and beyond. Theory \& Psychology, 28(5), 575-580. https://doi.org/10.1177/0959354318799210.

Pignati, W. A., Lima, F. A. N., d. S., Lara, S. S. d., Correa, M. L. M., Barbosa, J. R., Leão, L. H. d. C., , et al. (2017). Distribuição espacial do uso de agrotóxicos no Brasil: uma ferramenta para a Vigilância em Saúde. Ciência \& Saúde Coletiva, 22, 3281-3293. https://doi.org/10.1590/S0303-76572012000100004.

Pimentel, S. (2012). Cosmopolítica Kaiowá e Guarani: Uma crítica ameríndia ao agronegócio [Kaiowá and Guarani cosmopolitics:a amerindian critique of agribusiness]. Revista de Antropologia da UFSCar, 4(2), 134150. http://www.rau.ufscar.br/wp-content/uploads/2015/05/vol4no2_08.SPENSY.pdf

Pimentel, S. K. (2012). Elementos para uma teoria política Kaiowá e Guarani [Elements of a Kaiowá and Guarani political theory] (Doctoral dissertation, Universidade de São Paulo, São Paulo, Brazil). https:// www.teses.usp.br/teses/disponiveis/8/8134/tde-28022013-094259/publico/2012_SpensyKmittaPimentel_ VCorr.pdf

Pimentel, S. K. (2017). Contra o que protesta o kaiowa que vai a forca? Uma reflexão etnográfica sobre percepções não indígenas frente a intenções e sentimentos indígenas[Against what do the Kaiowá who hangs himself/herself protest? An ethnographic reflectin about non-indigenous perceptions against indigenous intentions and sentiments]. In L. Campo Aráuz \& M. Aparicio (Eds.), Etnografias del suicidio en América del Sur [Ethnographies of suicide in South America]. (pp. 285-311.) Quito: Editorial Universitaria Abya-Yala.

Polkinghorne, D. E. (1988). Narrative knowing and the human sciences. Albany: State University of New York Press.

Porto-Gonçalves, C. W. (2008). Outra verdade inconveniente-a nova geografia política da energia numa perspectiva subalterna [Another inconvenient truth- a new political geography of energy in a subaltern perspective]. Universitas Humanística(66), 327-365. http://www.scielo.org.co/pdf/unih/n66/n66a17.pdf

Rogoff, B. (2003). The cultural nature of human development. New York: Oxford University Press.

Rosset, P. M., Machín Sosa, B., Roque Jaime, A. M., \& Ávila Lozano, D. R. (2011). The Campesino-toCampesino agroecology movement of ANAP in Cuba: social process methodology in the construction of sustainable peasant agriculture and food sovereignty. The Journal of Peasant Studies, 38(1), 161191. https://doi.org/10.1080/03066150.2010.538584.

Sauer, S. (2018). Soy expansion into the agricultural frontiers of the Brazilian Amazon: The agribusiness economy and its social and environmental conflicts. Land Use Policy, 79, 326-338. https://doi. org/10.1016/j.landusepol.2018.08.030.

Sauer, S., Pietrafesa, J. P., \& Pietrafesa, P. A. (2017). Climate change and agrofuels: Brazilian ethanol and the Cerrado biome. In M. Angelo \& A. Plessis (Eds.), Research handbook on climate change and agricultural law (pp. 331-366). Cheltenham: Edward Elgar Publishing.

Teo, T. (2010). What is epistemological violence in the empirical social sciences? Social and Personality Psychology Compass, 4(5), 295-303. https://doi.org/10.1111/j.1751-9004.2010.00265.x.

Trawick, P., Hornborg, A., Cliggett, L., Friedman, J., Gudeman, S., Kassam, K.-A.S., et al. (2015). Revisiting the image of limited good: On sustainability, thermodynamics, and the illusion of creating wealth. Current Anthropology, 56(1), 000-000. https://doi.org/10.1086/679593.

Urt, J. N. (2016). How Western Sovereignty Occludes Indigenous Governance: The Guarani and Kaiowa Peoples in Brazil. Contexto Internacional, 38(3), 865-886. https://doi.org/10.1590/s0102-8529.2016380300007.

Valsiner, J. (2014). Needed for cultural psychology: Methodology in a new key. London, UK: Sage.

Vázquez, R. (2011). Translation as erasure: Thoughts on modernity's epistemic violence. Journal of Historical Sociology, 24(1), 27-44. https://doi.org/10.1111/j.1467-6443.2011.01387.x.

Vygotsky, L. S. (2004). Imagination and creativity in childhood. Journal of Russian \& East European Psychology, 42(1), 7-97. https://doi.org/10.1080/10610405.2004.11059210.

wa Thiong'o, N. . (2009). Something torn and new: An African renaissance. New York: Basic Civitas Books.

Weis, L., \& Fine, M. (2012). Critical bifocality and circuits of privilege: Expanding critical ethnographic theory and design. Harvard Educational Review, 82(2), 173-201. https://doi.org/10.17763/ haer.82.2.v1jx34n441532242.

White, M. K. (2007). Maps of narrative practice. New York: WW Norton \& Company.

Whyte, K. (2017). Indigenous climate change studies: Indigenizing futures, decolonising the anthropocene. English Language Notes, 55(1), 153-162. https://www.muse.jhu.edu/article/711473.

Wilkinson, J., \& Herrera, S. (2010). Biofuels in Brazil: Debates and impacts. The Journal of Peasant Studies, 37(4), 749-768. https://doi.org/10.1080/03066150.2010.512457. 
Woodbury, Z. (2019). Climate trauma: Toward a new taxonomy of trauma. Ecopsychology, 11(1), 1-8. https:// doi.org/10.1089/eco.2018.0021.

Zittoun, T. (2019). Sociocultural psychology on the regional scale: A case study of a hill. Cham, Switzerland: Springer.

Zittoun, T., \& Gillespie, A. (2015). Imagination in human and cultural development. London: Routledge.

Publisher's Note Springer Nature remains neutral with regard to jurisdictional claims in published maps and institutional affiliations. 